\title{
Prevalence, antibiotic susceptibility, and presence of drug resistance genes in Aeromonas spp. isolated from freshwater fish in Kelantan and Terengganu states, Malaysia
}

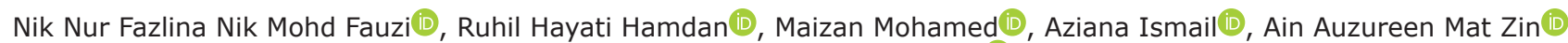
and Nora Faten Afifah Mohamad(D)

Department of Paraclinical Studies, Faculty of Veterinary Medicine, Universiti Malaysia Kelantan, Pengkalan Chepa, 16100 Kota Bharu, Kelantan, Malaysia.

Corresponding author: Ruhil Hayati Hamdan, e-mail: ruhil@umk.edu.my

Co-authors: NNFNMF: nnfazlina@gmail.com, MM: maizan.m@umk.edu.my, AI: aziana.ismail@gmail.com, AAMZ: ainauzureen@gmail.com, NFAM: fatenfieyfa@gmail.com

Received: 31-03-2021, Accepted: 29-06-2021, Published online: 10-08-2021

doi: www.doi.org/10.14202/vetworld.2021.2064-2072 How to cite this article: Fauzi NNFNM, Hamdan RH, Mohamed M, Ismail A, Zin AAM, Mohamad NFA (2021) Prevalence, antibiotic susceptibility, and presence of drug resistance genes in Aeromonas spp. isolated from freshwater fish in Kelantan and Terengganu states, Malaysia, Veterinary World, 14(8): 2064-2072.

\begin{abstract}
Background and Aim: The emergence of antibiotic-resistant bacterial pathogens has been increasingly reported, which has resulted in a decreasing ability to treat bacterial infections. Therefore, this study investigated the presence of Aeromonas spp., including its antibiotic resistance in various fish samples, Oreochromis spp., Clarias gariepinus, and Pangasius hypophthalmus, obtained from Kelantan and Terengganu, Malaysia.

Materials and Methods: In this study, 221 fish samples, of which 108 (Oreochromis spp., $\mathrm{n}=38 ;$ C. gariepinus, $\mathrm{n}=35$; and P. hypophthalmus, $\mathrm{n}=35$ ) were from Kelantan and 113 (Oreochromis spp., $\mathrm{n}=38$; C. gariepinus, $\mathrm{n}=35$; and P. hypophthalmus, $\mathrm{n}=40$ ) were from Terengganu, were caught using cast nets. Then, samples from their kidneys were cultured on a Rimler Shott agar to isolate Aeromonas spp. Polymerase chain reaction (PCR) was used to confirm this isolation using specific gene primers for species identification. Subsequently, the isolates were tested for their sensitivity to 14 antibiotics using the Kirby-Bauer method, after which the PCR was conducted again to detect resistance genes: sull, strA-strB, aadA, bla $\mathrm{TEM}_{\mathrm{TEM}}$, bla ${ }_{\mathrm{SHV}}$ tetA-tetE, and tetM.

Results: From the results, 61 isolates were identified as being from the genus Aeromonas using PCR, of which 28 were Aeromonas jandaei, 19 were Aeromonas veronii, seven were Aeromonas hydrophila, and seven were Aeromonas sobria. Moreover, 8, 12, and 8 of A. jandaei; 4, 3, and 12 of A. veronii; 6, 0, and 1 of A. hydrophila; and 3, 3, and 1 of A. sobria were obtained from Oreochromis spp., C. gariepinus, and P. hypophthalmus, respectively. In addition, the isolates showed the highest level of resistance to ampicillin (100\%), followed by streptomycin $(59.0 \%)$, each kanamycin and nalidixic acid $(41.0 \%)$, neomycin $(36.1 \%)$, tetracycline (19.7\%), sulfamethoxazole (14.8\%), and oxytetracycline (13.1\%). Resistance to gentamicin and ciprofloxacin both had the same percentage $(9.8 \%)$, whereas isolates showed the lowest resistance to norfloxacin $(8.2 \%)$ and doxycycline (1.6\%). Notably, all Aeromonas isolates were susceptible to chloramphenicol and nitrofurantoin. Results also revealed that the multiple antibiotic resistances index of the isolates ranged from 0.07 to 0.64 , suggesting that the farmed fish in these areas were introduced to the logged antibiotics indiscriminately and constantly during their cultivation stages. Results also revealed that the sull gene was detected in $19.7 \%$ of the Aeromonas isolates, whereas the tetracycline resistance genes, tetA and tetE, were detected in $27.9 \%$ and $4.9 \%$ of the isolates, respectively. However, $\beta$-lactam resistance genes, bla $_{\mathrm{TEM}}$ and $b l a_{\mathrm{SHV}}$, were found in $44.3 \%$ and $13.1 \%$ of Aeromonas isolates, respectively, whereas strA-strB and aadA genes were found in $3.3 \%$ and $13.1 \%$ of the isolates, respectively.
\end{abstract}

Conclusion: This study, therefore, calls for continuous surveillance of antibiotic-resistant Aeromonas spp. in cultured freshwater fish to aid disease management and better understand their implications to public health.

Keywords: Aeromonas, antibiotic resistance genes, antibiotic susceptibility, freshwater fish.

\section{Introduction}

Aquaculture plays an important role in the food supply of Malaysia. Under the Economic Transformation Program, the Malaysian government established aquaculture as one of the key thrust areas

Copyright: Fauzi, et al. Open Access. This article is distributed under the terms of the Creative Commons Attribution 4.0 International License (http://creativecommons.org/licenses/by/4.0/), which permits unrestricted use, distribution, and reproduction in any medium, provided you give appropriate credit to the original author(s) and the source, provide a link to the Creative Commons license, and indicate if changes were made. The Creative Commons Public Domain Dedication waiver (http://creativecommons.org/ publicdomain/zero/1.0/) applies to the data made available in this article, unless otherwise stated. for the agro-food industry [1]. In 2014, Malaysia's annual per capita fish intake was one of the highest in Asia at $56.5 \mathrm{~kg}$, with tilapia (Oreochromis spp.) and African catfish (Clarias gariepinus) being the favored farmed fish. Interestingly, in freshwater aquaculture, the African (C. gariepinus) and Pangasius (Pangasius hypophthalmus) catfishes being produced are leading because of a higher local demand, followed by tilapia (Oreochromis spp.), which is small in terms of production and was valued at RM223,000 (USD 58,000) [1].

Despite these interesting facts, bacterial infections are the most growing contagious concern in industrial fish farms and ornamental fish [2]. Studies 
have shown that captive fish are susceptible to many pathogenic bacteria that can cause kidney disease, dropsy, enteric redmouth, tuberculosis, vibriosis, motile aeromonad septicemia, bacterial gill infection, mouth fungus, tail and fin rot, and columnaris [3-7]. Furthermore, one of the most emerging bacteria that cause infectious diseases in freshwater aquaculture worldwide is Aeromonas hydrophila and other aeromonads [8,9]. These Aeromonas species can also cause motile aeromonads septicemia (MAS) in fish, with clinical symptoms, such as ulceration, ascitis, scale detachment, erosion, and exophthalmia being reported [10]. Apart from A. hydrophila, many disease-related aeromonads have been identified in tilapia as well, such as Aeromonas sobria [11], Aeromonas dhakensis (A. hydrophila subspecies dhakensis) [12], and Aeromonas veronii (synonyms of Aeromonas ichthiosmia, Aeromonas culicicola, and Aeromonas allosaccharophila) [13-16]. However, the occurrence of $A$. hydrophila infection was significantly higher in cultured fish than in wild species, such as Nile tilapia [17].

Antimicrobials have progressively been used in animal farming for disease prevention and treatment over the past few years, including as growth promoters [18]. However, their usage is based on modern medicine; the misuse of these antibiotics has increased the risk of emerging antimicrobial resistance cases in pathogenic and nonpathogenic bacteria. This has resulted in the lower treatment potency of commonly used antimicrobials in treating diseases, such as tuberculosis, pneumonia, and gastrointestinal infections, in humans [19]. In addition, during animal farming, antimicrobial deposits have been discovered in terrestrial, freshwater, and marine habitats close to agriculture and aquaculture facilities [20,21]. Antimicrobials are also applied in the feed or directly to water in aquaculture systems. Thus, they are proposed to subsequently be disposed into the environment by run-off water, sedimentation of feces, or uneaten feed pellets that can then be eaten by local fish or invertebrates [21-25]. The unconstrained use of antimicrobials in aquaculture can therefore transmit antibiotic-resistant bacteria, which are commonly transferred through $\mathrm{R}$ plasmids, with fish bacteria acting as intermediates [18,20,22,26-31].

Therefore, this study investigated the presence of Aeromonas spp., including its antibiotic resistance in various fish samples, Oreochromis spp., Clarias gariepinus, and Pangasius hypophthalmus, obtained from Kelantan and Terengganu, Malaysia.

\section{Materials and Methods}

\section{Ethical approval}

The study was approved by the Institutional Animal Care and Use Committee (IACUC), Faculty of Veterinary Medicine, University Malaysia Kelantan (UMK/FPV/ACUE/PG/4/2019).

\section{Study period and location}

This study was conducted from February 2019 to December 2019. Samples were taken from three freshwater fish farms, each in state of Kelantan and Terengganu. In Kelantan, the farms located in Tumpat, Kota Bharu and Bachok. In Terengganu, two farms located in Kuala Terengganu and one farm in Hulu Terengganu. All the samples were processed in situ with an aseptic technique.

\section{Sample collection}

Here, 221 freshwater fish were collected, with 108 samples from Kelantan and 113 samples from Terengganu. Of the 108 fish samples from Kelantan, 38 were red hybrid tilapia (Oreochromis spp.), 35 were African catfish (C. gariepinus), and the remaining 35 were Pangasius catfish (P. hypophthalmus). However, of the 113 fish samples collected from Terengganu, 38 were Oreochromis spp., 35 were C. gariepinus, and 40 were $P$. hypophthalmus. Next, a specimen of the kidneys was collected from these fish.

\section{Bacterial isolation and identification}

The specimen was inoculated on Rimler Shott agar (RSA) (HiMedia, India) supplemented with novobiocin antibiotics and incubated at $30^{\circ} \mathrm{C}$ for $24 \mathrm{~h}$. Next, yellow colonies on RSA were chosen and further sub-cultured on Trypticase soy agar (TSA) (Oxoid, Hampshire, UK) for purity. Subsequently, morphological and biochemical tests were used to identify all isolates, such as Gram staining, oxidase, catalase, and motility tests, after which the biochemical characteristics of Aeromonas spp. were examined using the analytical profile index 20E kit (bioMerieux, France) according to the manufacturer's instructions. Finally, the strip was incubated at $30^{\circ} \mathrm{C}$ for $24 \mathrm{~h}$.

\section{Confirmation of Aeromonas spp. using polymerase chain reaction (PCR) assay}

Genomic DNA was extracted using the Bacterial Genomic DNA kit (Geneaid, USA) following the manufacturer's instructions. To determine the presence of Aeromonas spp., a PCR assay was then conducted using 16S rRNA and a specific gene [32]. Next, PCR amplification was conducted using a Mastercycler gradient (Bio-Rad, USA). A final PCR volume of $25 \mu \mathrm{L}$ containing $12.5 \mu \mathrm{L}$ Go $\mathrm{Taq}^{\circledR}$ Green Master Mix (Promega, USA), $1 \mu \mathrm{L}$ of each $10 \rho \mathrm{mol}$ forward and reverse primers, and $2 \mu \mathrm{L}$ DNA template were used. The conditions for thermocycling were set as follows: $94^{\circ} \mathrm{C}$ for $3 \mathrm{~min}, 35$ cycles of $94^{\circ} \mathrm{C}$ for $60 \mathrm{~s}$, $58^{\circ} \mathrm{C}$ for $60 \mathrm{~s}, 72^{\circ} \mathrm{C}$ for $1.5 \mathrm{~min}$, and a final extension at $72^{\circ} \mathrm{C}$ for $3 \mathrm{~min}$. Finally, amplified products were electrophoresed on $2.0 \%$ agarose gels, after which the gels were visualized and captured using GelDoc (Bio-Rad).

Determination of antibiotic susceptibility and multiple antibiotic resistance (MAR) index of selected bacteria

The isolates were tested for sensitivity to 14 antibiotics: Ampicillin $(10 \mu \mathrm{g})$, gentamicin $(10 \mu \mathrm{g})$, neomycin $(30 \mu \mathrm{g})$, streptomycin $(10 \mu \mathrm{g})$, kanamycin $(30 \mu \mathrm{g})$, tetracycline $(30 \mu \mathrm{g})$, oxytetracycline $(30 \mu \mathrm{g})$, ciprofloxacin $(5 \mu \mathrm{g})$, norfloxacin $(10 \mu \mathrm{g})$, nalidixic 
acid $(30 \mu \mathrm{g})$, chloramphenicol $(30 \mu \mathrm{g})$, sulfamethoxazole $(25 \mu \mathrm{g})$, doxycycline $(30 \mu \mathrm{g})$, and nitrofurantoin $(300 \mu \mathrm{g})$. Kirby-Bauer's disc diffusion method was then used to assess the patterns of antibiotic sensitivity of the isolates. Inhibition zone results were subsequently interpreted as sensitive (S), intermediate (I), and resistant $(\mathrm{R})$ according to the reference standard by the Clinical and Laboratory Standard Institute [33].

MAR index was calculated using the formula provided by Sarter et al. [34]:

\section{$\mathrm{X} /(\mathrm{Y} \times \mathrm{Z})$}

Where, $\mathrm{X}=$ Total cases of antibiotic resistance; $\mathrm{Y}=$ Total number of isolates; $\mathrm{Z}=$ Total number of isolates

The MAR index value of equal to, or less than, 0.2 was defined as antibiotics that were seldom or never used.

\section{Detection of associated drug resistance genes}

Resistance genes were detected using PCR amplification with the different primers as described in Table-1 [35-41]. Assays were then conducted in $25 \mu \mathrm{L}$ volume mixtures, according to the manufacturer's protocol (Promega, USA). Next, all PCR reactions were subjected to amplification according to the cycling parameter suggested by a previous researcher (Table-1). Finally, PCR products were run on $2.0 \%$ agarose, after which the gel was visualized and captured using Gel Doc (Bio-Rad).

\section{Results}

From the results, 61 isolates obtained from freshwater fish samples were identified as genus Aeromonas using PCR. Table-2 shows that from the 61 Aeromonas spp. isolated, 22 isolates were from
P. hypophthalmus, 19 from Oreochromis spp., and 20 from C. gariepinus. Furthermore, Aeromonas species isolated from freshwater fish in Kelantan were higher (43 isolates) than those from Terengganu (18 isolates).

Figure-1 shows the confirmed identification using the PCR assay of Aeromonas spp. The positive isolates for the 16S rRNA gene were then sent for sequencing. Figure-2 shows the distribution of Aeromonas species

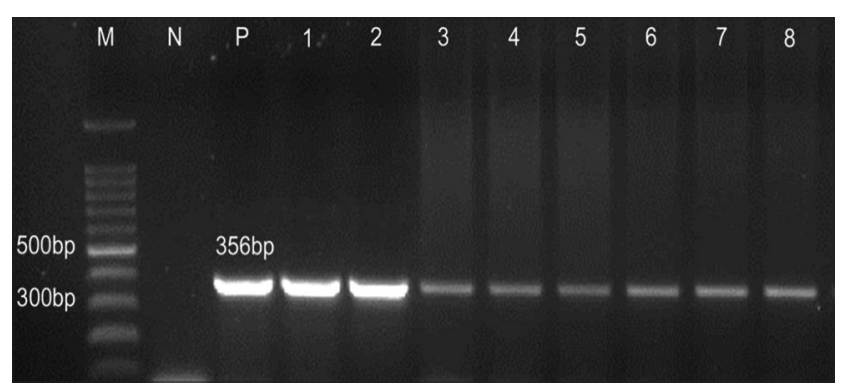

Figure-1: Representative of polymerase chain reaction (PCR) positives for 16S rRNA of genus Aeromonas. Lane M: 1 Kbp DNA marker (Promega, USA); Lane N: negative control; Lane P: positive control; Lanes 1-8: Positive Aeromonas with 356 bp PCR products.

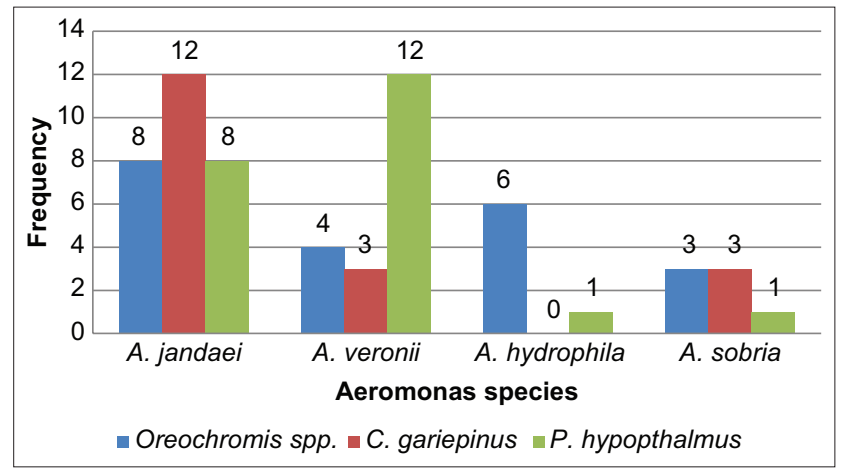

Figure-2: Distribution of Aeromonas species isolated from freshwater fish.

Table-1: List of primers used for detection of antibiotic resistance genes.

\begin{tabular}{|c|c|c|c|}
\hline Primer & Nucleotide sequence $\left(5^{\prime}-3^{\prime}\right)$ & Product size (bp) & References \\
\hline sul1-F & CTTCGATGAGACCCGGCGGC & 436 & [35] \\
\hline sul1-R & GCAAGGCGGAAACCCGCGCC & & \\
\hline aadA-F & GAGAACATAGCGTTGCCTTGGTCG & 198 & [36] \\
\hline $\operatorname{aad} A-R$ & GCGCGATTTTGCCGGTTA & & \\
\hline strA-strB-F & TTGAATCGAACTAATAT & 1640 & [37] \\
\hline strA-strB-R & CTAGTATGACGTCTGTCG & & \\
\hline blaTEM-F & ATGAGTATTCAACATTTCCG & 867 & [38] \\
\hline blaTEM-R & CTGACAGTTACCAATGCTTA & & \\
\hline blaSHV-F & GGTTATGCGTTATATTCGCC & 867 & [38] \\
\hline blaSHV-R & TTAGCTTTGCCAGTGCTC & & \\
\hline tetA-F & GTAATTCTGAGCACTGTCGC & 956 & {$[39,40]$} \\
\hline tetA-R & CTGCCTGGACAACATTGCTT & & \\
\hline tetB-F & CTCAGTATTCCAAGCCTTTG & 535 & {$[39,40]$} \\
\hline tetB-R & CTAAGCACTTGTCTCCTGTT & & \\
\hline tetC-F & TCTAACAATGCGCTCATCGT & 588 & {$[39,40]$} \\
\hline tetC-R & GGTTGAAGGCTCTCAAGGGC & & \\
\hline tetD-F & ATTACACTGCTGGACGCGAT & 1070 & {$[39,40]$} \\
\hline tetD-R & CTGATCAGCAGACAGATTGC & & \\
\hline tetE-F & GTGATGATGGCACTGGTCAT & 1198 & {$[39,40]$} \\
\hline tetE-R & СTCTGCTGTACATCGCTCTT & & \\
\hline tetM-F & GTTAAATAGTGTTCTTGGAG & 650 & {$[41]$} \\
\hline tetM-R & CTAAGATATGGCTCTAACAA & & \\
\hline
\end{tabular}


Table-2: Prevalence of Aeromonas spp. isolated from freshwater fish.

\begin{tabular}{lccc}
\hline Host species & \multicolumn{2}{c}{$\begin{array}{c}\text { Aeromonas Kelantan Terengganu } \\
\text { spp. } \\
\text { isolated (n) }\end{array}$} & $\begin{array}{c}\text { (n, \%) } \\
(\mathbf{n}, \mathbf{\%})\end{array}$ \\
\hline $\begin{array}{l}\text { Pangasius } \\
\text { hypophthalmus }\end{array}$ & 22 & $20(90.9)$ & $2(9.1)$ \\
$\begin{array}{l}\text { Oreochromis spp. } \\
\text { Clarias gariepinus }\end{array}$ & 19 & $9(47.4)$ & $10(52.6)$ \\
Total & 20 & $14(70.0)$ & $6(30.0)$ \\
\hline
\end{tabular}

according to each state in Kelantan and Terengganu. Four types of Aeromonas species were obtained during this study, with 28 isolates of Aeromonas jandaei, 19 isolates of $A$. veronii, seven isolates of $A$. hydrophila, and seven isolates of A. sobria. Furthermore, Aeromonas jandei and A. veronii were detected in both samples from Kelantan and Terengganu, whereas A. hydrophila and A. sobria were detected only in samples from Kelantan.

Figure-3 shows Aeromonas spp. colonies formed on TSA, which were creamy in color, round, and convex, whereas Aeromonas colonies on RSA were yellow-green in color, round, and convex. The biochemical test results from Aeromonas spp. isolates revealed Gram-negative staining, rod-shaped, motile, fermentative, oxidase-positive, catalase-positive, and indole negative characteristics.

In addition, all Aeromonas isolates displayed varying trends of resistance, where all isolates were ampicillin-resistant (100\%), followed by streptomycin $(59.0 \%)$, kanamycin and nalidixic acid with the same percentage $(41.0 \%)$, neomycin $(36.1 \%)$, tetracycline $(19.7 \%)$, sulfamethoxazole $(14.8 \%)$, and oxytetracycline $(13.1 \%)$. Gentamicin and ciprofloxacin both had the same percentage resistance $(9.8 \%)$, whereas norfloxacin $(8.2 \%)$ and doxycycline $(1.6 \%)$ had the lowest (Figure-4). However, all Aeromonas isolates were sensitive to chloramphenicol and nitrofurantoin.

Figure-5 shows the presence of antibiotic resistance genes in Aeromonas isolates. Results showed that the sull gene (related to sulfonamide resistance) was detected in $19.7 \%$ of the Aeromonas isolates. However, for tetracycline resistance genes, only tet $A$ and tet $E$ were detected in $27.9 \%$ and $4.9 \%$ of isolates, respectively. In addition, the $\beta$-lactam resistance genes, $b l a_{\mathrm{TEM}}$ and $b l a_{\mathrm{SHV}}$, were found in $44.3 \%$ and $13.1 \%$ of Aeromonas isolates, respectively, whereas the strA-strB gene (related to streptomycin resistance) was found in $3.3 \%$ of the isolates, and the aadA gene (related to streptomycin and spectinomycin resistance) in $13.1 \%$ of the isolates. Table- 3 shows the resistance phenotype and antibiotic resistance genes of all Aeromonas spp. isolates.

\section{Discussion}

$\mathrm{H}_{2} \mathrm{~S}$ production is one of the features of Aeromonas spp. pathogenic piscine strains [42]. Shotts and Rimler [43] indicated that Aeromonas spp. grown on an RSA medium formed yellow colonies; however,

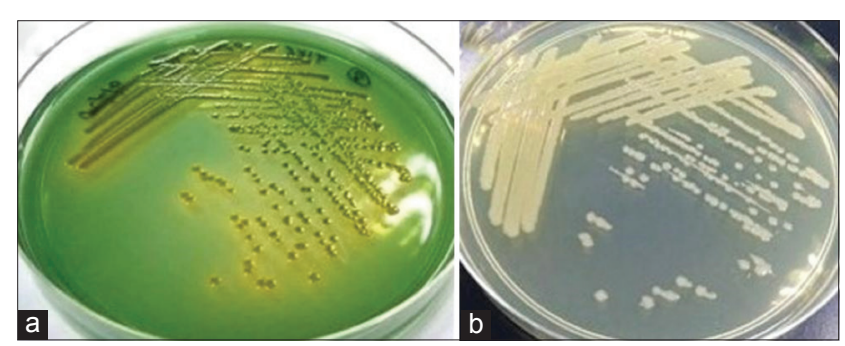

Figure-3: Aeromonas veronii on; (a) Rimler Shott agar; (b) Trypticase Soy agar.

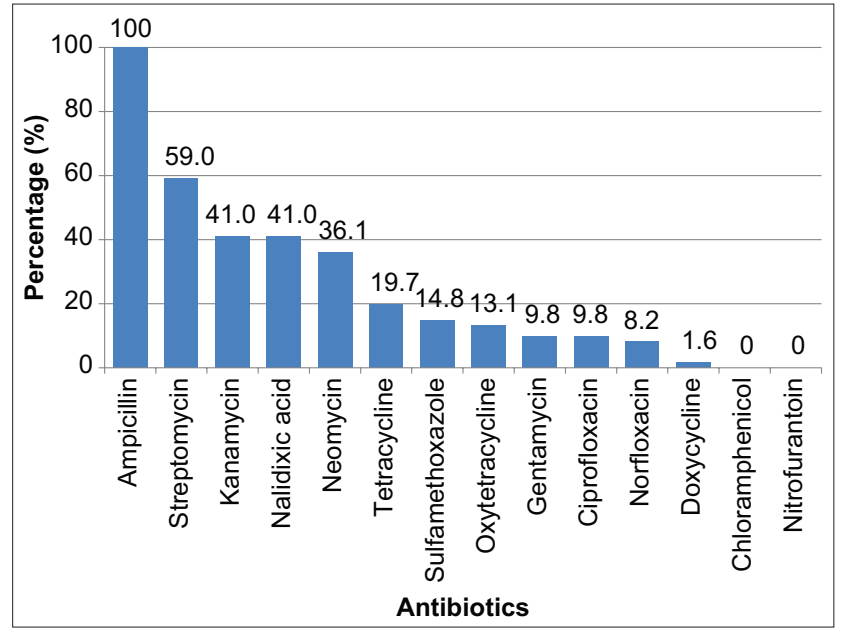

Figure-4: Antibiotic resistant of Aeromonas isolates.

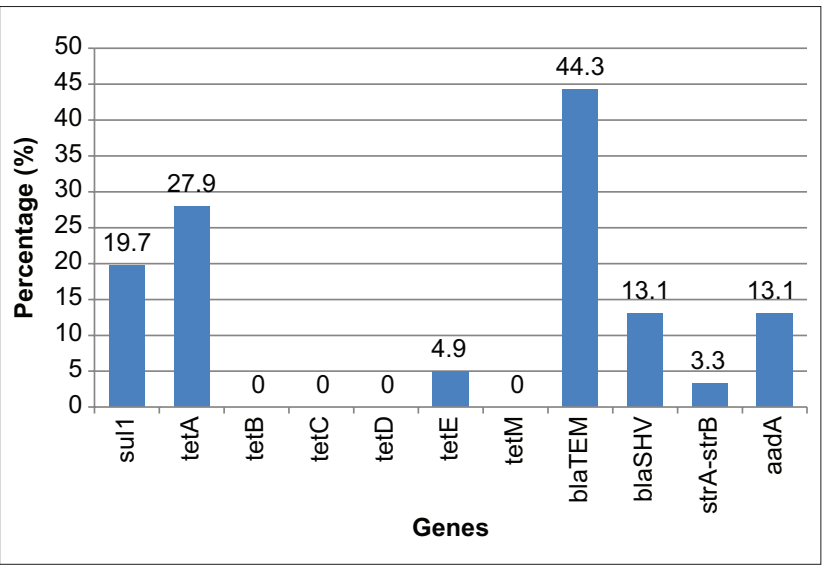

Figure-5: The presence of antibiotic resistance genes in Aeromonas isolated from freshwater fish.

the colonies with black centers had to be tested for oxidase production to exclude the probability of Citrobacter spp. or other species of bacteria. MAS is broad, which includes A. hydrophila and several species of Aeromonas that have been reported to be risks to freshwater fish in aquaculture $[13,14,44,45]$. Motile aeromonad infections are possibly the most significant bacterial infection in freshwater fish. They are also discovered regularly in the intestines and gills of freshwater fish. Therefore, in this study, bacteria of the genus Aeromonas were isolated from the kidneys of red hybrid tilapia (Oreochromis spp.), including African (C. gariepinus) and Pangasius (P. hypophthalmus) catfishes obtained from the states of Kelantan and Terengganu in Malaysia. 
Table-3: Resistance phenotype and presence of antibiotic resistance genes in Aeromonas spp. isolated from freshwater fish.

\begin{tabular}{|c|c|c|c|c|c|c|c|}
\hline No. & Isolates & Identification & Fish species & Location & $\begin{array}{l}\text { Resistance } \\
\text { phenotype }\end{array}$ & $\begin{array}{l}\text { Genes detected } \\
\text { by PCR }\end{array}$ & $\begin{array}{l}\text { MAR } \\
\text { Index }\end{array}$ \\
\hline 1. & $\mathrm{~K} 1 \mathrm{~K} 2$ & A. sobria & C. gariepinus & Kelantan & Amp-N-S-K & bla $_{T E M^{\prime}}$ bla $_{S H V}$ & 0.29 \\
\hline 2. & K1K3 & A. sobria & C. gariepinus & Kelantan & Amp-N-S-K-Na-Sxt & sul1, tetA & 0.43 \\
\hline 3. & $\mathrm{~K} 2 \mathrm{~K} 11$ & A. jandaei & C. gariepinus & Kelantan & Amp-S-Na-Sxt-Ot & - & 0.36 \\
\hline 4. & $\mathrm{~K} 2 \mathrm{~K} 12$ & A. sobria & C. gariepinus & Kelantan & $\begin{array}{l}\text { Amp-N-S-K-Te-Cip- } \\
\text { Na-Ot }\end{array}$ & tetA & 0.57 \\
\hline 5. & K2K15 & A. jandaei & C. gariepinus & Kelantan & Amp-N-S-K-Na & bla $_{T E M}$ & 0.36 \\
\hline 6. & $\mathrm{~K} 2 \mathrm{~K} 16$ & A. veronii & C. gariepinus & Kelantan & $\begin{array}{l}\text { Amp-N-S-K-Na- } \\
\text { Sxt-Ot }\end{array}$ & sul1, tetE, bla ${ }_{T E M}$ & 0.50 \\
\hline 7. & K3K22 & A. veronii & C. gariepinus & Kelantan & Amp-Te-Na-Ot & bla $_{T E M}$ & 0.29 \\
\hline 8. & K3K24 & A. jandaei & C. gariepinus & Kelantan & Amp-N-S & bla $_{T E M}$ & 0.21 \\
\hline 9. & K3K25 & A. veronii & C. gariepinus & Kelantan & Amp-Te-Na-Sxt-Ot & sul1, tetA, bla ${ }_{T E M}$ & 0.36 \\
\hline 10. & K3K26 & A. jandaei & C. gariepinus & Kelantan & Amp-S & bla $_{T E M}$ & 0.14 \\
\hline 11. & K3K27 & A. jandaei & C. gariepinus & Kelantan & Amp & bla $_{T E M}$ & 0.07 \\
\hline 12. & K3K28 & A. jandaei & C. gariepinus & Kelantan & Amp & $-\quad$ TEM & 0.07 \\
\hline 13. & K3K29 & A. jandaei & C. gariepinus & Kelantan & Amp-N-S-K-Na-Ot & $\begin{array}{l}\text { tetA, strA-strB, } \\
\text { bla }_{T E M}\end{array}$ & 0.43 \\
\hline 14. & K3K30 & A. jandaei & C. gariepinus & Kelantan & Amp-S-Na & tetA, bla & 0.21 \\
\hline 15. & $\mathrm{~K} 1 \mathrm{P} 2$ & A. sobria & P. hypopthalmus & Kelantan & Amp-N-S-K-Te-Na & $\begin{array}{l}\text { tet } A, \text { strA-strB, } \\
\operatorname{aad} A\end{array}$ & 0.43 \\
\hline 16. & K1P5 & A. veronii & P. hypopthalmus & Kelantan & Amp & - & 0.07 \\
\hline 17. & $\mathrm{~K} 2 \mathrm{P} 1$ & A. hydrophila & P. hypopthalmus & Kelantan & Amp & - & 0.07 \\
\hline 18. & $\mathrm{~K} 2 \mathrm{P} 2$ & A. jandaei & P. hypopthalmus & Kelantan & Amp-Te & tetE & 0.14 \\
\hline 19. & $\mathrm{~K} 2 \mathrm{P} 3$ & A. jandaei & P. hypopthalmus & Kelantan & Amp-Na & - & 0.14 \\
\hline 20. & $\mathrm{~K} 2 \mathrm{P} 4$ & A. veronii & P. hypopthalmus & Kelantan & Amp-S & - & 0.14 \\
\hline 21. & K2P5 & A. veronii & P. hypopthalmus & Kelantan & Amp-S-K & $b^{\prime} / a_{T E M}$ & 0.21 \\
\hline 22. & K2P6 (a) & A. veronii & P. hypopthalmus & Kelantan & Amp & - & 0.07 \\
\hline 23. & K2P6 (b) & A. veronii & P. hypopthalmus & Kelantan & Amp-N-K & bla $_{T E M}$ & 0.21 \\
\hline 24. & $\mathrm{~K} 2 \mathrm{P} 7$ & A. jandaei & P. hypopthalmus & Kelantan & Amp-S & - & 0.14 \\
\hline 25. & $\mathrm{~K} 2 \mathrm{P} 8(\mathrm{a})$ & A. jandaei & P. hypopthalmus & Kelantan & Amp-S-K & $b^{\prime} / a_{T E M}$ & 0.21 \\
\hline 26. & K2P8 (b) & A. jandaei & P. hypopthalmus & Kelantan & Amp-N-S-K-Na & bla $_{T E M^{\prime}}$ bla ${ }_{S H V}$ & 0.36 \\
\hline 27. & $\mathrm{~K} 2 \mathrm{P} 10$ & A. veronii & P. hypopthalmus & Kelantan & Amp-S-K & - & 0.21 \\
\hline 28. & K3P4 & A. jandaei & P. hypopthalmus & Kelantan & Amp-S-K & - & 0.21 \\
\hline 29. & K3P5 (a) & A. veronii & P. hypopthalmus & Kelantan & Amp-S-K & - & 0.21 \\
\hline 30 & K3P5 (b) & A. veronii & P. hypopthalmus & Kelantan & Amp-S-K & bla $_{T E M}$ & 0.21 \\
\hline 31. & K3P6 (a) & A. veronii & P. hypopthalmus & Kelantan & Amp-N-S-K & bla $_{T E M^{\prime}}$ bla ${ }_{S H V}$ & 0.29 \\
\hline 32. & K3P6 (b) & A. veronii & P. hypopthalmus & Kelantan & Amp-S-K & $-\quad T E M P S O H V$ & 0.21 \\
\hline 33. & K3P9 (a) & A. veronii & P. hypopthalmus & Kelantan & Amp-S-K & $b^{\prime} a_{T E M}$ & 0.21 \\
\hline 34. & K3P9 (b) & A. veronii & P. hypopthalmus & Kelantan & Amp-S-K & - & 0.21 \\
\hline 35. & $\mathrm{~K} 1 \mathrm{~T} 2$ (a) & A. hydrophila & Oreochromis spp. & Kelantan & $\begin{array}{l}\text { Amp-Cn-N-S-K-Cip- } \\
\text { Nor-Na-Sxt }\end{array}$ & $\begin{array}{l}\text { sul1, tet } A, b^{\prime} a_{T E M M^{\prime}} \\
\text { bla }_{S H V^{\prime}} \text { aadA }\end{array}$ & 0.64 \\
\hline 36. & K1T2 (b) & A. sobria & Oreochromis spp. & Kelantan & $\begin{array}{l}\text { Amp-N-S-K-Te-Na- } \\
\text { Sxt }\end{array}$ & sul1, tet $A$, bla $a_{T E M}$ & 0.50 \\
\hline 37. & $\mathrm{~K} 2 \mathrm{T3}(\mathrm{a})$ & A. sobria & Oreochromis spp. & Kelantan & $\begin{array}{l}\text { Amp-Cn-N-S-K-Cip- } \\
\text { Nor-Na-Sxt }\end{array}$ & $\begin{array}{l}\text { sul1, tet } A, \text { bla } \\
\text { bla }_{\text {THN }} \text { aadA }\end{array}$ & 0.64 \\
\hline 38. & K2T3 (b) & A. sobria & Oreochromis spp. & Kelantan & Amp-N-S-Te-Na & $\operatorname{tet} A$, bla ${ }_{T E M^{\prime}}$ aad $A$ & 0.36 \\
\hline 39. & K2T6 (a) & A. hydrophila & Oreochromis spp. & Kelantan & Amp-N-S-Te-Na & tetA, bla ${ }_{T E M^{\prime}}$ aad $A$ & 0.36 \\
\hline 40. & K2T6 (b) & A. hydrophila & Oreochromis spp. & Kelantan & $\begin{array}{l}\text { Amp-Cn-N-S-K-Na- } \\
\text { Sxt }\end{array}$ & sul1, tetA, bla & 0.50 \\
\hline 41. & K3T8 & A. hydrophila & Oreochromis spp. & Kelantan & $\begin{array}{l}\text { Amp-Cn-N-S-K-Te- } \\
\text { Cip-Nor-Na }\end{array}$ & tetA, bla ${ }_{T E M^{\prime}}$ bla $a_{S H V}$ & 0.64 \\
\hline 42. & K3T10 & A. hydrophila & Oreochromis spp. & Kelantan & $\begin{array}{l}\text { Amp-Cn-N-S-K-Te- } \\
\text { Cip-Nor-Na }\end{array}$ & $\begin{array}{l}\text { tet } A, \text { bla } \\
\text { bla }_{\text {TEM }} \text {, aadA }\end{array}$ & 0.64 \\
\hline 43. & K3T11 & A. hydrophila & Oreochromis spp. & Kelantan & $\begin{array}{l}\text { Amp-Cn-N-S-Cip- } \\
\text { Nor-Na-Sxt }\end{array}$ & $\begin{array}{l}\text { sul1, tet } A, \text { bla } \\
\text { bla }_{S N^{\prime} M^{\prime}} \text { aadA }\end{array}$ & 0.57 \\
\hline 44. & $\mathrm{~T} 2 \mathrm{~K} 5$ & A. jandaei & C. gariepinus & Terengganu & Amp-Na & tetE & 0.14 \\
\hline 45. & $\mathrm{~T} 2 \mathrm{~K} 4$ & A. jandaei & C. gariepinus & Terengganu & Amp & - & 0.07 \\
\hline 46. & T3K6 & A. jandaei & C. gariepinus & Terengganu & Amp-Te-Na-Do-Ot & tet $A$ & 0.36 \\
\hline 47. & T3K8 & A. jandaei & C. gariepinus & Terengganu & Amp & - & 0.07 \\
\hline 48. & T1T7 & A. jandaei & Oreochromis spp. & Terengganu & Amp & sul1 & 0.07 \\
\hline 49. & T1T10 (b) & A. veronii & Oreochromis spp. & Terengganu & Amp & sul1, aad $A$ & 0.07 \\
\hline 50. & T1T4 (a) & A. jandaei & Oreochromis spp. & Terengganu & Amp & sul1 & 0.07 \\
\hline 51. & T1K6 & A. veronii & Oreochromis spp. & Terengganu & Amp-N-Te-Sxt-Ot & sul 1 , tet $A$ & 0.36 \\
\hline 52. & $\mathrm{~T} 1 \mathrm{~K} 7$ & A. veronii & Oreochromis spp. & Terengganu & Amp-S & - & 0.14 \\
\hline 53. & T1T6 & A. jandaei & Oreochromis spp. & Terengganu & Amp-Na-S & - & 0.21 \\
\hline 54. & T1T9 & A. veronii & Oreochromis spp. & Terengganu & Amp & - & 0.07 \\
\hline 55. & $\mathrm{~T} 2 \mathrm{~T} 1$ & A. jandaei & Oreochromis spp. & Terengganu & Amp & - & 0.07 \\
\hline
\end{tabular}


Table-3: (Continued)

\begin{tabular}{|c|c|c|c|c|c|c|c|}
\hline No. & Isolates & Identification & Fish species & Location & $\begin{array}{l}\text { Resistance } \\
\text { phenotype }\end{array}$ & $\begin{array}{l}\text { Genes detected } \\
\text { by PCR }\end{array}$ & $\begin{array}{l}\text { MAR } \\
\text { Index }\end{array}$ \\
\hline 56. & T2T3 & A. jandaei & Oreochromis spp. & Terengganu & Amp & bla $_{T E M}$ & 0.07 \\
\hline 57. & T2T5 (a) & A. jandaei & Oreochromis spp. & Terengganu & Amp & - & 0.07 \\
\hline 58. & T2T6 & A. jandaei & Oreochromis spp. & Terengganu & Amp-S & - & 0.14 \\
\hline 59. & T2T7 & A. jandaei & Oreochromis spp. & Terengganu & Amp-Na-S & - & 0.21 \\
\hline 60. & T1P8 & A. jandaei & P. hypopthalmus & Terengganu & Amp & - & 0.07 \\
\hline 61. & T2P3 & A. jandaei & P. hypopthalmus & Terengganu & Amp & - & 0.07 \\
\hline
\end{tabular}

Amp=Ampicillin $(10 \mu \mathrm{g}), \mathrm{Cn}=$ Gentamicin $(10 \mu \mathrm{g}), \mathrm{N}=$ Neomycin $(30 \mu \mathrm{g}), \mathrm{S}=$ Streptomycin $(10 \mu \mathrm{g}), \mathrm{K}=$ Kanamycin $(30 \mu \mathrm{g}), \mathrm{Te}=$ Tetracycline $(30 \mu \mathrm{g})$, Cip=Ciprofloxacin $(5 \mu \mathrm{g})$, Nor=Norfloxacin $(10 \mu \mathrm{g}), \mathrm{Na}=$ Nalidixic acid $(30 \mu \mathrm{g})$, Sxt=Sulfamethoxazole $(25 \mu \mathrm{g}), \mathrm{C}=$ Chloramphenicol $(30 \mu \mathrm{g})$, Do=Doxycycline $(30 \mu \mathrm{g})$, F=Nitrofurantoin (300 $\mu \mathrm{g})$, $\mathrm{Ot}=$ Oxytetracycline $(30 \mu \mathrm{g})$. MAR=Multiple antibiotic resistance, $\mathrm{PCR}=$ Polymerase chain reaction, $A$. sobria=Aeromonas sobria, C. gariepinus=Clarias gariepinus, $A$. jandaei=Aeromonas jandaei, $A$. veronii=Aeromonas veronii,

$P$. hypopthalmus=Pangasiusr hypopthalmus, $A$. hydrophila=Aeromonas hydrophila

Furthermore, among the 61 isolates from the genus Aeromonas isolated, 28 isolates were A. jandaei, 19 were $A$. veronii, and seven isolates were $A$. hydrophila and $A$. sobria, respectively. These results are in agreement with those observed in earlier studies by Radu et al. [46] that found A. veronii, A. sobria, A. hydrophila, and $A$. caviae in the market fish samples from Selangor state in Malaysia. In India, $A$. hydrophila has also been isolated from fish obtained from retail shops [47]. In addition, Ashiru et al. [48] isolated A. hydrophila, A. caviae, and A. sobria in catfish (Clarias betrachus) and tilapia fish (Tilapia nilotica) obtained from the Makoko market in Nigeria. The authors reported that A. caviae was predominant in tilapia fish, whereas A. hydrophila and A. sobria were predominant in catfish. Other studies have also reported that $A$. jandaei is pathogenic to aquaculture fish, such as European eels (Anguilla anguilla) [49] and Pangasius catfish ( $P$. hypophthalmus) [50]. Besides, other studies have shown that $A$. veronii infected high numbers of fish, such as Chinese long snout catfish (Leiocassis longirostris) [51], loach (Misgurnus anguillicaudatus) [45], Oscar (Astronotus ocellatus) [52], and tilapia (Oreochromis spp.) [13,14,44]. This bacterial genus attacks catfish, which is among the main freshwater resources, and infects all sizes of fish as well, which can lead to death and result in big losses of freshwater fish production [53].

Aeromonas genus generates single or MARs rapidly, indicating that this genus is an effective marker of antimicrobial resistance in the freshwater aquaculture system [54]. The MAR index varying from 0.07 to 0.64 with $60 \%(37 / 61)$ of the isolates have MAR indices of more than 0.2 (high-risk source of contamination), suggesting that the Aeromonas spp. in these farmed fish have been exposed to a high level of antibiotics during the cultivation processes, which can result in the development of antibiotic resistance among the bacteria isolates. Results from this study prove this fact, which revealed a high level of multidrug resistance (MDR) among the isolates tested (Table-3). However, the percentage of MAR index of more than 0.2 in this study $(60 \%)$ was much lower than that obtained from the study by Odeyemi and
Ahmad [55] in Aeromonas spp., isolated from 53 aquatic samples in Melaka, Malaysia (100\%). This result indicates that the indiscriminate use of antibiotics in West Coast Malaysia (Melaka) is higher than in East Coast Malaysia (Kelantan and Terengganu). High resistance of MDR due to Aeromonas spp. has also been reported as serious public health pathogens that cause gastroenteritis, septicemia, and skin infections in humans, which enter the human body through contaminated food and water consumption, including skin lesions [56].

In this study, all Aeromonas isolates were highly ampicillin-resistant. A previous study reported that these Aeromonas species acquired $\beta$-lactams resistance through the expression of chromosomal lactamases [57]. This finding is also proposed to be due to a high intrinsic $\beta$-lactam resistance, which is enhanced by an active efflux mechanism or cooperation through external membrane impermeability or secondary resistance mechanisms known as $\beta$-lactamases or antibiotic efflux pumps $[54,57,58]$. Furthermore, resistance rates to tetracycline, oxytetracycline, streptomycin, kanamycin, nalidixic acid, neomycin, sulfamethoxazole, ciprofloxacin, and gentamicin have also been recorded, which is suggested to be due to the extensive consumption of such antimicrobials in the ornamental fishery [59,60]. All isolates were also susceptible to chloramphenicol and nitrofurantoin. This observation is due to that these antibiotics were banned in Malaysia for use in treating aquatic animal diseases [61]. Several antibiotics were completely banned as well for food animals and aquaculture in Malaysia because of serious toxicity and the development of antibiotic-resistant bacterial strains, such as avoparcin, chloramphenicol, nitrofurans (i.e., nitrofurantoin, nitrofurazone, furazolidone, and furaltadone), teicoplanin, vancomycin, and norfloxacin $[61,62]$.

Furthermore, in this study, no trends of significant antibiotic resistance specific to the fish species were observed. The current findings follow other research on MDR occurrence from aquatic habitats and seafood samples in Aeromonas spp. [63,64]. These classes of antibiotics are broadly used worldwide as 
well, particularly in developing countries in Asia, because of their low cost and diverse-spectrum antimicrobial activity, which increases the chances for any bacterial species to develop resistance to these antibiotics $[65,66]$.

The presence of resistance genes was also detected in several of the isolates during this study, including those encoding resistance to ampicillin $\left(b l a_{\mathrm{TEM}}\right.$ and $\left.b l a_{\mathrm{SHV}}\right)$, streptomycin (aadA and strA$s t r B$ ), and tetracyclines (tet $A$ and tetE). The present findings agree with earlier studies where tet $A$ genes were the most significant determinants of tetracycline resistance and have commonly been observed in Aeromonas spp. [39,67]. Increased resistance to $\beta$-lactam antimicrobials (penicillins and derivatives, cephalosporins, carbapenems, and monobactams) through the existence of genes that code for the formation of $\beta$-lactamase has also been reported [68]. In addition, Jones-Dias et al. [69] mentioned that in Aeromonas spp., three main $\beta$-lactamases were identified: Metallo- $\beta$-lactamase Class B, cephalosporinase Class C, and penicillinase Class D. Fosse et al. [70] have also categorized the $\beta$-lactamases into five $(i * v)$ groups of Aeromonas species: (i) The A. hydrophila complex strains exhibiting Classes B, C, and D $\beta$-lactamases; (ii) the $A$. caviae strains exhibiting Classes $\mathrm{C}$ and $\mathrm{D} \beta$-lactamases; (iii) the $A$. veronii strains identifying Classes B and D lactamases; (iv) the Allium schubertii strains recognizing Class D lactamases; and (v) the Aeromonas trota strains containing Class C $\beta$-lactamases. It is also suggested that several isolates of $A$. veronii biovar sobria do contain a class $\mathrm{C}$ cephalosporinase [58]. Therefore, because of the presence of $\beta$-lactamase genes, increased resistance to $\beta$-lactam antibiotics was reported in the Aeromonas genus $[4,68,71,72]$.

\section{Conclusion}

This study has identified several Aeromonas spp. that are resistant to several types of antibiotics in freshwater fish from Kelantan and Terengganu states, with $60 \%(37 / 61)$ of the isolates having a MAR index of more than 0.2 . The result suggests that aquaculture waste deposited into the aquatic ecosystems is one of the factors that enhance the incidence of aeromonad MDR in the river water. The presence of Aeromonas species in freshwater fish can thus be a major problem if the fish is not cooked properly. This drug resistance has become a major public health concern since these fish species (Oreochromis spp., C. gariepinus, and $P$. hypophthalmus) are important sources of aquatic proteins consumed in Malaysia. Therefore, regular surveillance for antibiotic resistance of Aeromonas spp. should be conducted among freshwater fish. Finally, more intensive studies should discover the specific existence of antibiotic resistance in Aeromonas spp., including the levels of antibiotics that affect their resistance profile.

\section{Authors' Contributions}

NNFNMF: Designed the study and drafted the manuscript. MM, RHH, AI, AAMZ, and NFAM: Data analysis. RHH and MM: Direction and supervision of the study. All authors read and approved the final manuscript.

\section{Acknowledgments}

This study was funded by the Fundamental Research Grant Scheme (FRGS/1/2015/WAB01/ UMK/03/2) under Ministry of Higher Education, Malaysia. The authors also would like to thank the Department of Fisheries, Malaysia, for providing information on fish farming sites in Kelantan and Terengganu.

\section{Competing Interests}

The authors declare that they have no competing interests.

\section{Publisher's Note}

Veterinary World remains neutral with regard to jurisdictional claims in published institutional affiliation.

\section{References}

1. DoF (Department of Fisheries). (2015) Available from: https://www.dof.gov.my/epms/index.php/pages/view/2614. Retrieved on 02-06-2020

2. Sousa, H. and Hinzmann, M. (2020) Review: Antibacterial components of the Bivalve's immune system and the potential of freshwater bivalves as a source of new antibacterial compounds. Fish Shell. Immunol., 98: 971-980.

3. Aberoum, A. and Jooyandeh, H. (2010) A review on occurrence and characterization of the Aeromonas species from marine fishes. World J. Fish Mar. Sci., 2(6): 519-523.

4. Carvalho, M.J., Martínez-Murcia, A., Esteves, A.C., Correia, A. and Saavedra, M.J. (2012) Phylogenetic diversity, antibiotic resistance and virulence traits of Aeromonas spp. from untreated waters for human consumption. Int. J. Food Microbiol., 159(3): 230-239.

5. Ghenghesh, K.S., Ahmed, S.F., El-Khalek, R.A.,Al-Gendy, A. and Klena, J. (2008) Aeromonas-associated infections in developing countries. J. Infect. Dev. Ctries., 2(2): 81-98.

6. Lee, S.W. and Wee, W. (2012) Characterization of Vibrio alginolyticus isolated from white leg shrimp (Litopenaeus vannamei) with emphasis on its antibiogram and heavy metal resistance pattern. Vet. Arh., 82(2): 221-227.

7. Abbott, S.L., Cheung, W.K.W. and Janda, J.M. (2003) The genus Aeromonas: Biochemical characteristics, atypical reactions, and phenotypic identification schemes. J. Clin. Microbiol., 41(6): 2348-2357.

8. Dong, H.T., Techatanakitarnan, C., Jindakittikul, P., Thaiprayoon, A., Taengphu, S., Charoensapsri, W., Khunrae, P., Rattanarojpong, T. and Senapin, S. (2017) Aeromonas jandaei and Aeromonas veronii caused disease and mortality in Nile tilapia, Oreochromis niloticus (L.). J. Fish Dis., 40(10): 1395-1403.

9. Hassan, M.A., Noureldin, E.A., Mahmoud, M.A. and Fita, N.A. Molecular identification and epizootiology of Aeromonas veronii infection among farmed Oreochromis niloticus in Eastern Province, KSA. Egypt. J. Aquat. Res., 43(2): 161-167.

10. Stratev, D. and Odeyemi, O.A. (2017) An overview of motile Aeromonas septicaemia management. Aquac. Int., 25: 1095-1105. 
11. Li, Y. and Cai, S.H. (2011) Identification and pathogenicity of Aeromonas sobria on Tail-rot disease in Juvenile Tilapia Oreochromis niloticus. Curr. Microbiol., 62(2): 623-627.

12. Soto-Rodriguez, S.A., Cabanillas-Ramos, J., Alcaraz, U., Gomez-Gil, B. and Romalde, J.L. (2013) Identification and virulence of Aeromonas dhakensis, Pseudomonas mosselii and Microbacterium paraoxydans isolated from Nile tilapia, Oreochromis niloticus, cultivated in Mexico. J. Appl. Microbiol., 115(3): 654-662.

13. Dong, H.T., Rodkhum, C., Le, H.D., Sangsuriya, P., Senapin, S., Jitrakorn, S., Jitrakorn, S., Saksmerprome, V. and Nguyen, V.V. (2015) Naturally concurrent infections of bacterial and viral pathogens in disease outbreaks in cultured Nile tilapia (Oreochromis niloticus) farms. Aquaculture, 448: 427-435.

14. Eissa, I.A.M., El-Lamei, M., Sherif, M., Youssef, F., Zaki, M.S. and Bakry, M. (2015) Detection of hemolysin gene and antibiogram of Aeromonas veronii biovar sobria isolated from mass mortalities in cultured Nile Tilapia in El-Sharkia governorate, Egypt," Life Sci. J., 43(2): 161-167.

15. Huys, G., Cnockaert, M. and Swings, J. (2005) Aeromonas culicicola Pidiyar et al. 2002 is a later subjective synonym of Aeromonas veronii Hickman-Brenner et al. 1987. Syst. Appl. Microbiol., 28(7): 604-609.

16. Nhung, P.H., Hata, H., Ohkusu, K., Noda, M., Shah, M.M. Goto, K. and Ezaki, T. (2007) Use of the novel phylogenetic marker dnaJ and DNA-DNA hybridization to clarify interrelationships within the genus Aeromonas. Int. J. Syst. Evol. Microbiol., 57(6): 1232-1237.

17. Ibrahem, M.D., Mostafa, M.M., Arab, R.M.H. and Rezk, M.A. (2008) Prevalence of Aeromonas hydrophila Infection in Wild and Cultured Tilapia Nilotica (O. niloticus) in. $8^{\text {th }}$ International Symposium on Tilapia In Aquaculture, United States. p1257-1271.

18. Van Boeckel, T.P., Brower, C., Gilbert, M., Grenfell, B.T., Levin, S.A., Robinson, T.P., Teillant, A. and Laxminarayan, R. (2015) Global trends in antimicrobial use in food animals. Proc. Natl. Acad. Sci. U. S. A., 112(18): 5649-5654.

19. Fair, R.J. and Tor, Y. (2014) Antibiotics and bacterial resistance in the $21^{\text {st }}$ century. Perspect. Medicin. Chem., 6: 25-64.

20. Nakayama, T., Hoa, T.T.T., Harada, K., Warisaya, M., Asayama, M., Hinenoya, A., Lee, J.W., Phu, T.M., Ueda, S., Sumimura, Y., Hirata, K., Phuong, N.T. and Yamamoto, Y. (2017) Water metagenomic analysis reveals low bacterial diversity and the presence of antimicrobial residues and resistance genes in a river containing wastewater from backyard aquacultures in the Mekong Delta, Vietnam. Environ. Pollut., 222: 294-306.

21. Rico, A. and Van den Brink, P.J. (2014) Probabilistic risk assessment of veterinary medicines applied to four major aquaculture species produced in Asia. Sci. Total Environ., 468-469: 630-641.

22. Andrieu, M., Rico, A., Phu, T.M., Huong, D.T.T., Phuong, N.T. and Van den Brink, P.J. (2015) Ecological risk assessment of the antibiotic enrofloxacin applied to Pangasius catfish farms in the Mekong Delta, Vietnam. Chemosphere, 119: 407-414.

23. Muziasari, W.I., Pitkänen, L.K., Sørum, H., Stedtfeld, R.D., Tiedje, J.M. and Virta, M. (2017) The resistome of farmed fish feces contributes to the enrichment of antibiotic resistance genes in sediments below baltic sea fish farms. Front. Microbiol., 7: 2137.

24. Rico, A., Phu, T.M., Satapornvanit, K., Min, J., Shahabuddin, A.M., Henriksson, P.J.G., Murray, F.J., Little, D.C., Dalsgaard, A. and Van den Brinka, P.J. (201) Use of veterinary medicines, feed additives and probiotics in four major internationally traded aquaculture species farmed in Asia. Aquaculture, 412-413(1): 231-243.

25. Buschmann, A.H., Tomova, A., Lopez, A., Maldonado, M.A., Henriquez, L.A., Ivanova, L., Moy, F., Godfrey, H.P. and
Cabello, F.C. (2012) Salmon aquaculture and antimicrobial resistance in the marine environment. PLoS One, 7(8): e42724.

26. Hatosy, S.M. and Martiny, A.C. (2015) The ocean as a global reservoir of antibiotic resistance genes. Appl. Environ. Microbiol., 81(21): 7593-7599.

27. Rico, A., Oliveira, R., McDonough, S., Matser, A., Khatikarn, J., Satapornvanit, K. (2014) Use, fate and ecological risks of antibiotics applied in tilapia cage farming in Thailand. Environ. Pollut., 191: 8-16.

28. Kümmerer, K. (2009) Antibiotics in the aquatic environment-a review-Part I. Chemosphere, 75(4): 417-434.

29. Baquero, F., Martínez, J.L. and Cantón, R. (2008) Antibiotics and antibiotic resistance in water environments. Curr. Opin. Biotechnol., 19(3): 260-265.

30. Robinson, T.P., Bu, D.P., Carrique-Mas, J., Fevre, E.M., Gilbert, M., Grace, D., Hay, S.I., Jiwakanon, J., Kakkar, M., Kariuki, S., Laxminarayan, R., Lubroth, J., Magnusson, U., Thi Ngoc, P., Van Boeckel, T.P., Woolhouse, M.E.J. (2016) Antibiotic resistance is the quintessential one health issue. Trans. R. Soc. Trop. Med. Hyg., 110(7): 377-380.

31. Marshall, B.M. and Levy, S.B. (2011) Food animals and antimicrobials: Impacts on human health. Clin. Microbiol. Rev., 24(4): 718-733.

32. Hussain, I.A., Jeyasekaran, G., Shakila, R.J., Raj, K.T. and Jeevithan, E. (2014) Detection of hemolytic strains of Aeromonas hydrophila and A. sobria along with other Aeromonas spp. from fish and fishery products by multiplex PCR. J. Food Sci. Technol., 51(2): 401-407.

33. CLSI. (2018) Performance Standards for Antimicrobial Susceptibility Testing, CLSI Supplement M100. $28^{\text {th }}$ ed. CLSI, Wayne, PA.

34. Sarter, S., Kha Nguyen, H.N., Hung, L.T., Lazard, J. and Montet, D. (2007) Antibiotic resistance in Gram-negative bacteria isolated from farmed catfish. Food Control, 18(11): 1391-1396.

35. Sundström, L., Rådström, P., Swedberg, G. and Sköld, O. (1988) Site-specific recombination promotes linkage between trimethoprim-and sulfonamide resistance genes. Sequence characterization of $d h f r V$ and sulI and a recombination active locus of Tn 21. MGG Mol. Gen. Genet., 213(2-3): 191-201.

36. Sunde, M. and Norström, M. (2005) The genetic background for streptomycin resistance in Escherichia coli influences the distribution of MICs. J. Antimicrob. Chemother., 56(1): 87-90.

37. Han, H.S., Koh, Y.J., Hur, J.S. and Jung, J.S. (2004) Occurrence of the strA-strB streptomycin resistance genes in Pseudomonas species isolated from kiwifruit plants. J. Microbiol., 42(4): 365-368.

38. Rasheed, J.K., Jay, C., Metchock, B., Berkowitz, F., Weigel, L., Crellin, J. (1997) Evolution of extended-spectrum $\beta$-lactam resistance (SHV-8) in a strain of Escherichia coli during multiple episodes of bacteremia. Antimicrob. Agents Chemother., 41(3): 647-653.

39. Schmidt, A.S., Bruun, M.S., Dalsgaard, I. and Larsen, L. (2001) Incidence, distribution, and spread of tetracycline resistance determinants and integron-associated antibiotic resistance genes among motile aeromonads from a fish farming environment article a prendre comme exemple et comportant les amorces pour les in. Appl. Environ. Microbiol., 67(12): 5675-5682.

40. Schmidt, A.S., Bruun, M.S., Larsen, J.L. and Dalsgaard, I. (2001) Characterization of class 1 integrons associated with R-plasmids in clinical Aeromonas salmonicida isolates from various geographical areas. J. Antimicrob. Chemother, 47(6): 735-743.

41. Aarestrup, F.M., Agerso, Y., Gerner-Smidt, P., Madsen, M. and Jensen, L.B. (2000) Comparison of antimicrobial resistance phenotypes and resistance genes in Enterococcus faecalis and Enterococcus faecium from humans in the community, broilers, and pigs in Denmark. Diagn. Microbiol. 
Infect. Dis., 37(2): 127-137.

42. Austin, B. and Austin, D.A. (2012) Bacterial Fish Pathogens: Disease of Farmed and Wild Fish. Ellis Horwood Ltd., Chichester.

43. Shoits, E.B. and Rimler, R. (1973) Medium for the isolation of Aeromonas hydrophila. Appl. Microbiol., 26(4): 550-553.

44. Peepim, T., Dong, H.T., Senapin, S., Khunrae, P. and Rattanarojpong, T. (2016) Epr3 is a conserved immunogenic protein among Aeromonas species and able to induce antibody response in Nile tilapia. Aquaculture, 464(1): 399-409.

45. Zhu, M., Wang, X.R., Li, J., Li, G.Y., Liu, Z.P. and Mo, Z.L. (2016) Identification and virulence properties of Aeromonas veronii bv. sobria isolates causing an ulcerative syndrome of loach Misgurnus anguillicaudatus. J. Fish Dis., 39(6): 777-7781.

46. Radu, S., Ahmad, N., Ling, F.H. and Reezal, A. (2003) Prevalence and resistance to antibiotics for Aeromonas species from retail fish in Malaysia. Int. J. Food Microbiol., 81(3): 261-266.

47. Kaskhedikar, M. and Chhabra, D. (2010) Multiple drug resistance in Aeromonas hydrophila isolates of fish. Vet. World, 3(2): 76-77.

48. Ashiru, A.W., Uaboi-Egbeni, P.O., Oguntowo, J.E. and Idika, C.N. (2011) Isolation and antibiotic profile of Aeromonas species from Tilapia Fish (Tilapia nilotica) and Catfish (Clarias batrachus). Pak. J. Nutr., 10(10): 982-986.

49. Esteve, C., Biosca, E. and Amaro, C. (1993) Virulence of Aeromonas hydrophila and some other bacteria isolated from European eels Anguilla anguilla reared in fresh water. Dis. Aquat. Organ., 16: 15-20.

50. Kumar, S.P., Shankar, R.S., Pasim, R.K., Sabayasaohi, P. and Kumar, D.N. (2019) Pathogenic status, antibiogram, adhesive characteristics, heavy metal tolerance and incidence of integrons of infected fish isolated Aeromonas spp. J. Sustain. Sci. Manage., 14(2): 21-35.

51. Cai, S.H., Wu, Z.H., Jian, J.C., Lu, Y.S. and Tang, J.F. (2012) Characterization of pathogenic Aeromonas veronii bv. veronii associated with ulcerative syndrome from Chinese longsnout catfish (Leiocassis longirostris günther). Braz. J. Microbiol., 43(1): 382-388.

52. Sreedharan, K., Philip, R. and Singh, I.S.B. (2011) Isolation and characterization of virulent Aeromonas veronii from ascitic fluid of oscar Astronotus ocellatus showing signs of infectious dropsy. Dis. Aquat. Organ., 94(1): 29-39.

53. Kusdarwati, R. Kismiyati, Sudarno, Kurniawan, H. and Prayogi, Y.T. (2017) Isolation and identification of Aeromonas hydrophila and Saprolegnia spp. on catfish (Clarias gariepinus) in floating cages in bozem moro Krembangan Surabaya. IOP Conf. Ser. Earth Environ. Sci., 55(1): 012038

54. Nguyen, H.N.K., Van, T.T.H., Nguyen, H.T., Smooker, P.M., Shimeta, J. and Coloe, P.J. Molecular characterization of antibiotic resistance in Pseudomonas and Aeromonas isolates from catfish of the Mekong Delta, Vietnam. Vet. Microbiol., 171(3-4): 397-405.

55. Odeyemi, O.A. and Ahmad, A. (2017) Antibiotic resistance profiling and phenotyping of Aeromonas species isolated from aquatic sources. Saudi J. Biol. Sci., 24(1): 65-70.

56. Igbinosa, I.H., Igumbor, E.U., Aghdasi, F., Tom, M. and Okoh, A.I. (2012) Emerging Aeromonas species infections and their significance in public health. Sci. World J., 2012: 625023

57. Tayler, A.E., Ayala, J.A., Niumsup, P., Westphal, K., Baker, J.A., Zhang, J.A., Zhang, L., Walsh, T.R.,
Wiedemann, B., Bennett, P.A., Avison, M.B. (2010) Induction of $\beta$-lactamase production in Aeromonas hydrophila is responsive to $\beta$-lactam-mediated changes in peptidoglycan composition. Microbiology, 156(8): 2327-2335.

58. Janda, J.M. and Abbott, S.L. (2010) The genus Aeromonas: Taxonomy, pathogenicity, and infection. Clin. Microbiol. Rev., 23(1): 35-73.

59. Cabello, F.C., Godfrey, H.P., Buschmann, A.H. and Dölz, H.J. (2016) Aquaculture as yet another environmental gateway to the development and globalisation of antimicrobial resistance. Lancet Infect. Dis., 16(7): e127-e133.

60. Dobiasova, H., Kutilova, I., Piackova, V., Vesely, T., Cizek, A. and Dolejska, M. (2014) Ornamental fish as a source of plasmid-mediated quinolone resistance genes and antibiotic resistance plasmids. Vet. Microbiol., 171(3-4): 413-421.

61. National Pharmaceutical Regulatory Agency. (2017) Ministry of Health Malaysia. List of Registered Veterinary Products. Available from: http://www.npra. moh.gov.my/images/reg.info/Veterinary/2017/LIST_OF REGISTERED_VETERINARY_PRODUCTS_2017.pdf. Retrieved on 22-12-2020.

62. European Food Safety Authority. (2015) Scientific opinion on nitrofurans and their metabolites in food. EFSA J., 13(6): 4140.

63. Deng, Y., Wu, Y., Jiang, L., Tan, A., Zhang, R. and Luo, L. (2016) Multi-drug resistance mediated by class 1 integrons in Aeromonas isolated from farmed freshwater animals. Front. Microbiol., 7: 935.

64. Dias, C., Mota, V., Martinez-Murcia, A. and Saavedra, M.J. (2012) Antimicrobial resistance patterns of Aeromonas spp. isolated from ornamental fish. J. Aquac. Res. Dev., 3(3): 131.

65. Luo, Y., Xu, L., Rysz, M., Wang, Y., Zhang, H. and Alvarez, P.J.J. (2011) Occurrence and transport of tetracycline, sulfonamide, quinolone, and macrolide antibiotics in the Haihe River basin, China. Environ. Sci. Technol., 45(5), 1827-1833.

66. Suzuki, S. and Hoa, P.T.P. (2012) Distribution of quinolones, sulfonamides, tetracyclines in aquatic environment and antibiotic resistance in Indochina. Front. Microbiol., $3: 67$.

67. Nawaz, M., Khan, S.A., Khan, A.A., Sung, K., Tran, Q., Kerdahi, K. and Steele, R. (2010) Detection and characterization of virulence genes and integrons in Aeromonas veronii isolated from catfish. Food Microbiol., 27(3): 327-331.

68. Ndi, O.L. and Barton, M.D. (2011) Incidence of class 1 integron and other antibiotic resistance determinants in Aeromonas spp. From rainbow trout farms in Australia. J. Antimicrob. Chemother, 34(8): 589-599.

69. Jones-Dias, D., Manageiro, V., Ferreira, E., Louro, D. and Caniça, M. (2014) Diversity of extended-spectrum and plasmid-mediated AmpC $\beta$-lactamases in Enterobacteriaceae isolates from Portuguese health care facilities. J. Microbiol., 52(6): 496-503.

70. Fosse, T., Giraud-Morin, C. and Madinier, I. (2003) Phénotypes de résistance aux $\beta$-lactamines dans le genre Aeromonas. Pathol. Biol., 51(5): 290-296.

71. Chen, P.L., Lamy, B. and Ko, W.C. (2016) Aeromonas dhakensis, an increasingly recognized human pathogen. Front. Microbiol., 7: 793.

72. Vega-Sánchez, V., Latif-Eugenin, F., Soriano-Vargas, E., Beaz-Hidalgo, R., Figueras, M.J., Aguilera-Arreola, M.G. and Castro-Escarpulli, G. (2014) Re-identification of Aeromonas isolates from rainbow trout and incidence of class 1 integron and $\beta$-lactamase genes. Vet. Microbiol., 172(3-4): 528-533. 